\section{Effectiveness of Squid Hydrolysate as a Home Lawn Fertilizer}

\author{
Joseph C. Fetter and Rebecca N. Brown ${ }^{1}$ \\ Department of Plant Sciences and Entomology, The University of Rhode \\ Island, Plant Sciences, 210 Woodward Hall, Kingston, RI 02881
}

\begin{abstract}
José A. Amador
Department of Natural Resources Science, The University of Rhode Island, Plant Sciences, 210 Woodward Hall, Kingston, RI 02881
\end{abstract}

Additional index words. perennial ryegrass, organic nitrogen, turf quality

\begin{abstract}
Consumer demand for cleaned squid generates a substantial amount of waste that must be properly disposed of, creating an economic burden on processors. A potential solution to this problem involves converting squid byproducts into an organic fertilizer, for which there is growing consumer demand. Organic fertilizers are reputed to offer advantages that synthetic fertilizers cannot provide, such as increasing soil water- and nutrient-holding capacity and promoting the growth of beneficial soil organisms. To evaluate the effectiveness of hydrolyzed squid waste as an organic fertilizer, we quantified soil fertility and turfgrass quality on perennial ryegrass turf (Lolium perenne L.) amended with two types of fertilizer: squid-based (SQ) or synthetic (SY). Field plots were established on an Enfield silt loam in Kingston, RI, and liquid (L) or granular (G) fertilizer formulations of squid or synthetic fertilizers were applied at 0,48 , 146, and $292 \mathrm{~kg}$ nitrogen/ha/year. Soil physical, chemical, and biological properties were determined monthly and turfgrass quality was determined periodically during the growing season in 2008 and 2009 . Squid hydrolysate applied as a liquid (SQL) and granular (SQG) fertilizer consistently provided high-quality, uniform turf when compared with synthetic fertilizer applied at the same rate. Soil concentrations of $\mathrm{NO}_{3}, \mathrm{NH}_{4}, \mathrm{PO}_{4}, \mathrm{pH}$, moisture, soil organic matter, $\mathrm{C}: \mathrm{N}$ ratio, and levels of trace metals were unaffected by fertilizer type, formulation, or rate throughout the two-year study. Both squid-based organic fertilizer formulations gave significantly higher microbial activity rates than their synthetic counterparts regardless of application rate. Conversion of squid processing byproducts into fertilizer has the potential to improve turfgrass quality while providing a sustainable solution to waste disposal problems in the seafood processing industry.
\end{abstract}

Nitrogen $(\mathrm{N})$ is the most important nutrient added to turf (Hull and Bushoven, 2001; Landschoot and Waddington, 1987). Nitrate $\left(\mathrm{NO}_{3}\right)$ and ammonium $\left(\mathrm{NH}_{4}\right)$ are the primary sources of $\mathrm{N}$ used for synthesis of amino acids, proteins, enzymes, nucleic acids, and chlorophyll (Brady and Weil, 2002). It is mainly provided to turfgrass in the form of fertilizer, although $\mathrm{N}$ from mineralization of soil organic matter (SOM) and precipitation can also enrich the soil $\mathrm{N}$ pool. Nitrogen applied to turfgrass is taken up by the plant but can also be immobilized by microorganisms, leached, lost in runoff, or lost to the atmosphere through denitrification and volatilization (McCarty et al., 2003).

Organic fertilizers are naturally low in $\mathrm{N}$ and rely on microbial activity to mineralize organic $\mathrm{N}$ into plant-available forms. This activity may enhance overall turf quality,

\footnotetext{
Received for publication 10 Dec. 2012. Accepted for publication 24 Jan. 2013.

The research was supported by funding from Rhode Island SeaGrant.

This paper forms part of the M.S. thesis of J.C.F.

${ }^{1}$ To whom reprint requests should be addressed; e-mail brownreb@uri.edu.
}

because $\mathrm{N}$ is released more slowly from organic $\mathrm{N}$ sources, over longer periods of time, than from synthetic fertilizers. When fertilizer $\mathrm{N}$ is released too quickly in too great a quantity, or too slowly relative to plant needs, plants can be stressed, affecting the health and quality of turfgrass (Christians, 1996; Hummel, 1989). As microbial biomass builds up in soil tial for $\mathrm{N}$ mineralization increases (Zuberer, 2005), increasing $\mathrm{N}$ availability to the turfgrass. Organic fertilizers thus have the potential to increase soil fertility and SOM content over the long term (Booze-Daniels and Schmidt, 1997; Nardi et al., 2004). Nevertheless, research on the effectiveness of organic fertilizers for turfgrass has produced variable results. For example, when turfgrass was maintained under intense, "championship conditions," higher quality turf was consistently observed when it was fertilized with synthetic rather than organic fertilizer (Rossi, 2006). Other studies have shown that management practices, rather than $\mathrm{N}$ source, stimulate microbial activity (Elliott and Des Jardin, 1999; Zuberer, 2005).

The conversion of squid waste (squid byproducts) into organic fertilizer may present a solution to problems associated with from addition of organic fertilizer, the poten- high disposal costs for squid processors. The economic burden of squid byproduct disposal, and the high $\mathrm{N}$ content associated with squid byproducts, suggests there is potential to develop a marketable product from waste.

To evaluate the effectiveness of hydrolyzed squid waste as an organic fertilizer, we quantified soil fertility and turfgrass quality from perennial ryegrass turf (Lolium perenne L.) amended with two types of fertilizer: SQ and SY.

\section{Materials and Methods}

Study site. The study was conducted at the Richard Skogley Turf Research Farm, University of Rhode Island in Kingston, RI. Experimental plots were established in June 2007 on an Enfield silt loam (coarse-silty over sandy or sandy-skeletal, mixed, active, mesic Typic Dystrudept) (Rector, 1981). The study site $\left(185.8 \mathrm{~m}^{2}\right)$ was previously planted with tall fescue (Festuca arundinacea L.) that was fertilized for the previous six growing seasons with $50-100 \mathrm{~kg} \mathrm{~N} /$ ha/year of slowrelease granular fertilizer (19N-5P-9K). Glyphosate was applied to the study site in the summer of 2007 to kill the tall fescue and the area plowed and maintained as tilled fallow for two months. It was then seeded with perennial ryegrass (Lolium perenne $\mathrm{L}$.) in the fall of 2007. The area was maintained as a home lawn, mowed weekly at a height of $3.8 \mathrm{~cm}$ using a reel mower. Clippings were not collected. Irrigation was applied to avoid wilt.

Fertilizer sources. Hydrolysis of squid byproducts (head, fin, viscera, and unclaimed mantles and tentacles obtained from Point Judith Fishermen's Co., Narragansett, RI) was carried out at a commercial processing facility (Ocean Cliff Corp., New Bedford, MA) as described previously by Lian et al. (2005). Liquid squid fertilizer was prepared by stabilizing the squid hydrolysate through addition of phosphoric acid $\left(85 \% \mathrm{H}_{3} \mathrm{PO}_{4}\right)$ to a final $\mathrm{pH}$ of 3.5 (to protect against microbial growth). Granular squid fertilizer was prepared by mixing concentrated squid hydrolysate (78\% moisture) with clay (APG Missouri Fire, 20-mesh; Bailey Ceramic Supply, Kingston, NY) at a ratio of $9 / 1(w t / w t)$ in an $11-\mathrm{L}$ Hobart mixer for $10 \mathrm{~min}$. The resulting mix was poured onto a stainless steel tray $(\approx 1 \mathrm{~cm}$ thick layer) and dried at $80{ }^{\circ} \mathrm{C}$ in a cabinet dryer for $\approx 7 \mathrm{~h}$ until a consistency suitable for extrusion was achieved. Extrusion was performed using a C.W. Brabender benchtop extruder (single screw, Prep Center VD-52; Duisburg, Germany) equipped with a 2.4-mmdiameter nozzle. The extruded pellets $(2.4 \times$ $6 \mathrm{~mm}$ ) were dried at $80^{\circ} \mathrm{C}$ to a final moisture content of $8 \%$ (Fetter et al., 2011).

The N-P-K contents of SQL and SQG were 3.3-7.3-2 and 7.2-1.2-2, respectively. Most of the $\mathrm{N}$ in the squid products was in water-insoluble forms; water-soluble $\mathrm{N}$ accounted for $13.4 \%$ of total $\mathrm{N}$ in SQL and $5.3 \%$ in SQG. Synthetic liquid fertilizer was obtained from Aquatrols (Cherry Hill, NJ) and had an N-P-K content of 20-9-20 with 
$7.6 \%$ ammonium $\mathrm{N}$ and $12.4 \%$ nitrate $\mathrm{N}(100 \%$ water-soluble). ProTurf SYG was purchased from a commercial outlet in Exeter, RI, and had an N-P-K content of 19-5-9. Watersoluble $\mathrm{N}$ accounted for $71 \%$ of the total $\mathrm{N}$ in SYG. Liquid squid fertilizer, SQG, SYG, and SYL had total carbon (C) contents of $3.3 \%$, $2.6 \%, 0.7 \%$, and $0.1 \%$, respectively. Squid hydrolysate had a much lower $\mathrm{C}: \mathrm{N}$ ratio (less than 1:1) compared with alternative organic fertilizers such as Milorganite ${ }^{\circledR}$, seed meal, or compost, which have ratios of $6: 1,7: 1$, and 15:1, respectively (Milwaukee Metropolitan Sewage District, 2013; Rynk et al., 1992).

Treatments. Five treatments were used: 1) SQL; 2) SQG; 3) synthetic liquid (SYL); 4) synthetic granular (SYG); or 5) no fertilizer (NF control). Each fertilizer was applied at 48,146 , and $292 \mathrm{~kg} \mathrm{~N} /$ ha/year. A randomized block design with four replicates was used with each plot measuring $1.52 \times$ $1.52 \mathrm{~m}\left(2.3 \mathrm{~m}^{2}\right)$.

Granular products were applied in four equal applications each year. Liquid products were applied in eight equal applications each year with 3 weeks between applications. The different application schedules were used because granular fertilizers take longer to break down and release $\mathrm{N}$ to the turfgrass. The perapplication rate of $\mathrm{N}$ for liquid products was half the rate for granular products. Liquid fertilizers were applied using a handheld, 152-cm long $\mathrm{CO}_{2}$ sprayer $(276 \mathrm{kPa}$; Teejet 8004 VS nozzle, size 50 screen). After application of liquid fertilizers, the plots were immediately irrigated to avoid fertilizer burn. Granular fertilizers were applied using a handheld shaker to distribute the product evenly.

Soil sampling and analysis. Soil samples were collected monthly between June and Nov. 2008 and again from May to Nov. 2009. A soil corer was used to extract $15 \mathrm{~cm}$ long $X$ $1.25-\mathrm{cm}$ diameter samples from individual plots. After disposing of the thatch layer, samples were placed in a plastic bag and transported to the laboratory where they were stored in the dark at $4{ }^{\circ} \mathrm{C}$.

Soil moisture was determined gravimetrically by drying $5 \mathrm{~g}$ of fresh soil at $105^{\circ} \mathrm{C}$ for $24 \mathrm{~h}$. Soil $\mathrm{pH}$ was determined using a 1:10 $(\mathrm{w} / \mathrm{v})$ soil/water ratio (Hendershot et al., 1993) and measured with a $\mathrm{pH}$ meter (Model UB-10; Denver Instruments, Denver, CO). Bicarbonate-extractable $\mathrm{PO}_{4}$ was extracted using the method of Schoenau and Karamanos (1993). Soil $\mathrm{NO}_{3}$ and $\mathrm{NH}_{4}$ were extracted with $2 \mathrm{~N} \mathrm{KCl}$ in a $1: 10(\mathrm{w} / \mathrm{v})$ soil/water ratio using the method of Keeney (1982). Microbial activity was determined using the dehydrogenase activity assay (Gong, 1997) adapted for microplates. The resulting extracts for soil $\mathrm{PO}_{4}, \mathrm{NO}_{3}, \mathrm{NH}_{4}$, and microbial activity were analyzed colorimetrically using a Bio-Tek ${ }^{\circledR}$ (Power Wave 340) microplate reader. Soil organic matter content was determined using the loss-on-ignition method by combustion in a furnace at $550{ }^{\circ} \mathrm{C}$ for $4 \mathrm{~h}$. Total $\mathrm{C}$ and $\mathrm{N}$ content of soil samples was determined using an Elemental Combustion System (CHNS-O; Costech Analytical Technologies Inc., Valencia,
CA). The heavy metal content of soil samples was analyzed using a Niton XL3t X-Ray Fluorescence Analyzer (Thermo Scientific, Billerica, MA).

Evaluation of turf quality. Turf quality was evaluated using a visual rating scale (1 to 10 scale; 1 = straw color turf with a high density of weeds, $10=$ dark green turf without weeds). Quality ratings were conducted in August and October of 2008. In 2009, quality was rated monthly from June to November.

Clipping biomass was determined in August and October of 2008 and July and October of 2009. Clippings were collected from an area of $2.3 \mathrm{~m}^{2}$ in the center of each plot using a $60-\mathrm{cm}$-wide push reel mower with a clippings basket. A 30-cm buffer zone was left on each side of the collection area to avoid contamination from surrounding treatments. Clippings were transferred to paper bags, dried for $14 \mathrm{~d}$ at room temperature, and weighed to determine biomass.

Statistical analyses. Data were analyzed using two models. A repeated-measures fourway analysis of variance (ANOVA) was used to examine rate, date, formulation (liquid or granular), and type (organic or synthetic) as the main effects along with two-way interactions. A repeated-measures two-way ANOVA with date and product as the main effects was used to compare products with the nofertilizer control. Date was included as the within-subjects effect in both analyses, reflecting that repeated sampling of plots violates the assumption of independence for ANOVA. Means separation was accomplished using Fisher's least significant difference (LSD) test with a significance level of $\alpha=0.05$. Mean separation tests were used to compare treatment levels to the no-fertilizer control and among treatment levels. Heavy metal data were analyzed using one-way ANOVA and means separation was accomplished using Fisher's LSD $(\alpha=0.05)$.

\section{Results and Discussion}

Turf quality. Turfgrass that displays uniformity and density along with high clipping production reflects sufficient $\mathrm{N}$ availability to the plant (Turgeon, 2012). Perennial ryegrass uses $\mathrm{N}$ most efficiently when temperatures are cool and adequate moisture is present (McCarty et al., 2003). Clipping production was greater in October than in July or August for all treatments (Fig. 1). There were significant interactions between application rate and all of the other model effects, so data were analyzed separately for each application rate. Mean clipping production across all four sampling dates for the NF treatment was $2.7 \mathrm{~g} \cdot \mathrm{m}^{-2}$ per week. Only the main effect of date was significant for plots fertilized at a rate of $48 \mathrm{~kg} \mathrm{~N} / \mathrm{ha} /$ year. Over the course of the experiment, clipping yields from these plots did not differ significantly from the NF control (Fig. 1)

There was a significant interaction $(P=$ 0.0024 ) between formulation and type for clipping production in plots fertilized at $146 \mathrm{~kg}$ $\mathrm{N} /$ ha/year. SQG produced the most clippings with a mean of $4.63 \mathrm{~g} \cdot \mathrm{m}^{-2}$ per week. Clipping yields for SYL and SYG were comparable with means of 4.58 and $4.05 \mathrm{~g} \cdot \mathrm{m}^{-2}$ per week, respectively. Squid liquid fertilizer yielded significantly fewer clippings than all of the other fertilizer treatments, only $3.22 \mathrm{~g} \cdot \mathrm{m}^{-2}$ per week. Overall clipping production significantly exceeded the NF control for all products except SQL (Fig. 1). Clipping production in SQL plots exceeded the NF control in October of both years but not during the summer months.

Plots receiving granular fertilizer at a rate of $292 \mathrm{~kg} \mathrm{~N} / \mathrm{ha} /$ year produced significantly $(P=0.0073)$ more clippings over the study period than plots receiving liquid fertilizer at the same rate. Fertilizer type had no effect except in Oct. 2008 when plots fertilized with the squid-based fertilizers produced significantly $(P=0.04)$ more clippings than plots fertilized with the synthetic fertilizers. The granular squid-based fertilizer produced the most clippings when applied at a rate of $292 \mathrm{~kg} \mathrm{~N} / \mathrm{ha} /$ year. It outperformed the NF control on all four sampling dates (Fig. 1) and produced significantly more clippings overall. The synthetic granular fertilizer was comparable to SQG, although it averaged only $5.01 \mathrm{~g} \cdot \mathrm{m}^{-2}$ per week compared with $6.77 \mathrm{~g} \cdot \mathrm{m}^{-2}$ per week for SQG. Both liquid fertilizers produced significantly fewer clippings than SQG with averages of 4.14 and $3.74 \mathrm{~g} \cdot \mathrm{m}^{-2}$ per week for SQL and SYL, respectively.

Turfgrass quality averaged 6.2 for the NF control, suggesting that overall soil fertility was good (Fig. 2). Fertilizer type had no significant effect on turfgrass quality. Granular products produced significantly better turf quality than liquid products in June 2009, but liquid products produced significantly better quality in Aug. 2009, and there were no significant differences on the other dates. None of the products significantly increased overall turf quality when applied at $48 \mathrm{~kg} \mathrm{~N} /$ ha/year with scores ranging from 6.4 to 6.8 (Fig. 2). Applications of 146 and $292 \mathrm{~kg} \mathrm{~N} /$ ha/year did significantly increase turf quality over the NF control for all products. Quality increased with fertilizer application rate above $48 \mathrm{~kg} \mathrm{~N} / \mathrm{ha} /$ year for all products. When quality was examined over the entire study period, there were no significant differences among the four products. Thus, the squid-based products delivered turf quality comparable to that achieved using synthetic fertilizers.

Our results differ from those of Landschoot and Waddington (1987), who found that kentucky bluegrass fertilized with sewage-based organic fertilizers at a rate of $196 \mathrm{~kg} \mathrm{~N} / \mathrm{ha} /$ year produced significantly poorer quality and fewer clippings than the same turf fertilized with synthetic $\mathrm{N}$ sources at the same rate. Similarly, Gaudreau et al. (2002) found that common bermudagrass produced significantly fewer clippings and had lower quality when fertilized with dairy manure than when fertilized with synthetic $\mathrm{N}$ fertilizer. Eguiza et al. (1991) found that a mixed stand of creeping bentgrass and annual bluegrass produced similar amounts of clippings when 


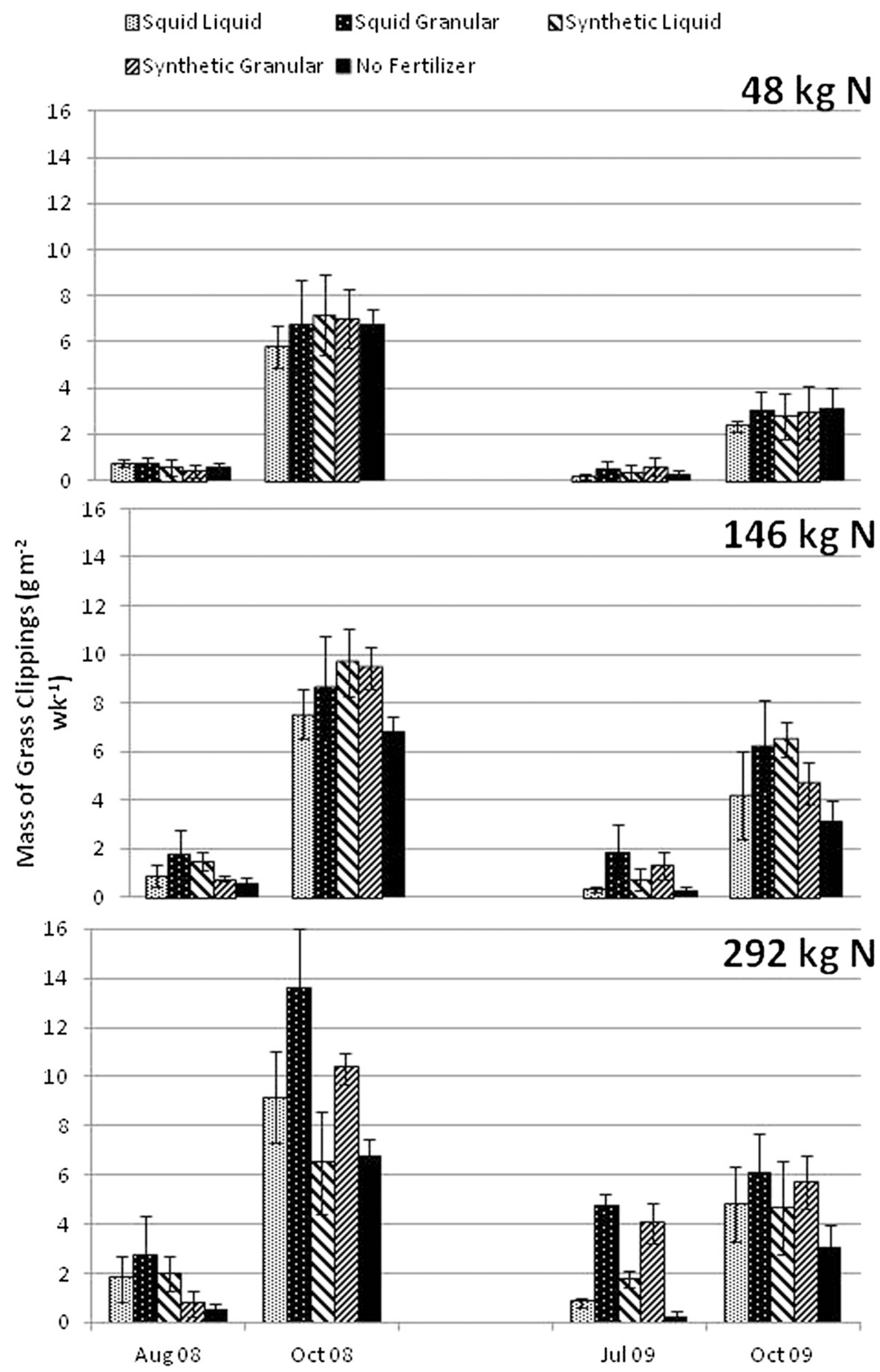

Fig. 1. Mean $(n=4)$ grass clipping production on four dates for four fertilizer products each applied at three rates and the no-fertilizer control. Error bars indicate 1 sD. 
fertilized with sulfur-coated urea and with Milorganite ${ }^{\circledR}$ at the same rate of $\mathrm{N}$ application but that turf quality was consistently higher when sulfur-coated urea was used. It should be noted that all of these studies used some form of manure, so they are not directly comparable to the squid hydrolysate in this study.

Soil properties. During the course of the two-year study, no significant differences were observed among treatments for levels of $\mathrm{NO}_{3}, \mathrm{NH}_{4}$, or $\mathrm{PO}_{4}$ in the soil or for soil $\mathrm{pH}$, soil moisture, or SOM (Table 1). Perennial ryegrass can use upward of $450 \mathrm{~kg} \mathrm{~N} /$ ha/year (Sullivan et al., 1999), so the grass had the potential to absorb all the applied N. Mean levels of inorganic $\mathrm{N}$ in soil ranged from 0.4 to $0.6 \mathrm{mg} \mathrm{N} / \mathrm{kg}$ for $\mathrm{NO}_{3}$ and 1.9 to $5.0 \mathrm{mg}$ $\mathrm{N} / \mathrm{kg}$ for $\mathrm{NH}_{4}$. These levels were similar to those reported by Bushoven et al. (2001) and Jiang et al. (2000) for studies of fertilizer effects on turf at the same location. Only low levels of $\mathrm{NO}_{3}$ were found in soil pore water from the plots in this study (Fetter et al., 2011). Several studies have shown that only a small fraction of $\mathrm{N}$ applied to turf is lost through volatilization and denitrification (Mancino et al., 1988; Torello et al., 1983). Most of the $\mathrm{N}$ applied in this study appears to have been taken up by the turfgrass regardless of the $\mathrm{N}$ source. This is further supported by evidence of increased clipping production and quality as $\mathrm{N}$ application rate increased among all treatments and by the lack of differences in quality between squid-based and synthetic products applied at the same $\mathrm{N}$ rate.

Organic fertilizers are often presumed to increase soil $\mathrm{PO}_{4}$ concentrations (Wright et al., 2008), which can increase the risk of environmental pollution (Ginting et al., 2003). Our results do not support these claims. The average soil $\mathrm{PO}_{4}$ concentration for the two seasons ranged from 8.3 to $10.0 \mathrm{mg} \cdot \mathrm{kg}^{-1}$,

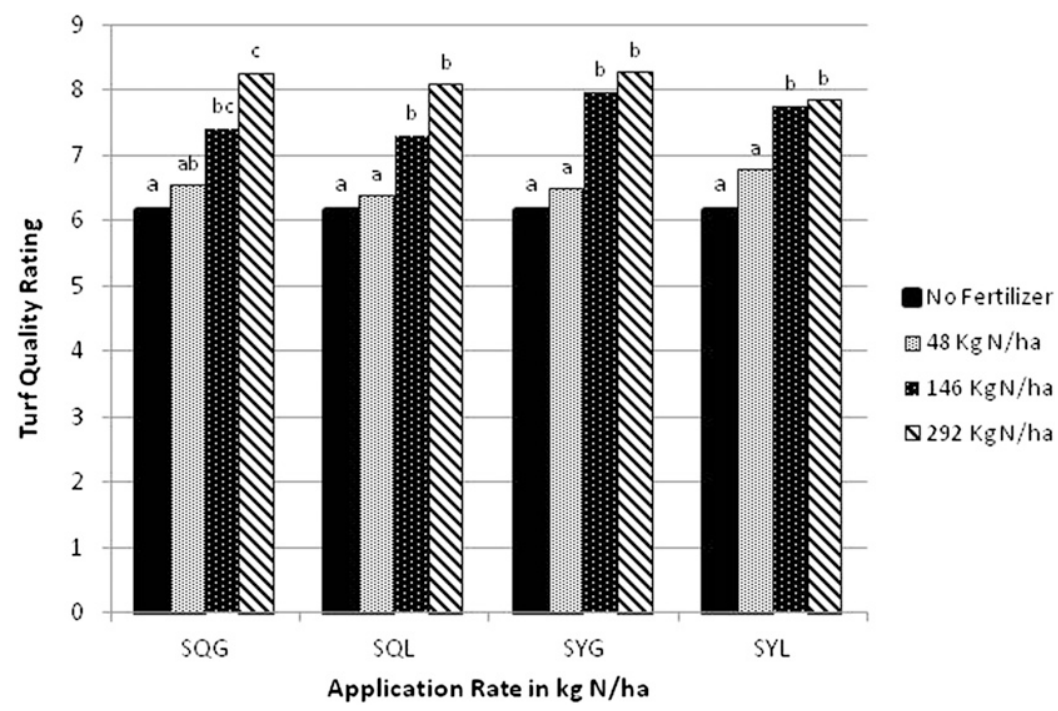

Fig. 2. Least square means from repeated measures analysis of turf quality in perennial ryegrass plots treated with four different fertilizers at three rates relative to the no-fertilizer control. Turf quality was visually evaluated using a 1 to 10 scale where $1=$ straw color turf with a high density of weeds and $10=$ dark green turf without weeds. Means represent four replications and eight rating dates over two years. Within each fertilizer grouping, columns labeled with the same letter were not significantly different at $\alpha=0.05 . \mathrm{SQG}=$ squid-based granular; $\mathrm{SQL}=$ squid-based liquid; $\mathrm{SYG}=$ synthetic granular; $\mathrm{SYL}=$ synthetic liquid.

Table 1. Soil properties for perennial ryegrass plots amended with squid hydrolysate liquid (SQL), squid hydrolysate granular (SQG), synthetic liquid (SYL), or synthetic granular (SYG) fertilizer at rates of 48 or $292 \mathrm{~kg}$ nitrogen $(\mathrm{N}) /$ ha/year, or no-fertilizer $(\mathrm{NF}) .^{\mathrm{z}}$

\begin{tabular}{|c|c|c|c|c|c|c|c|c|c|}
\hline \multirow[b]{3}{*}{ Soil property } & \multicolumn{8}{|c|}{ Application rate (kg N/ha/year) } & \multirow{3}{*}{$\frac{0}{\mathrm{NF}}$} \\
\hline & \multicolumn{4}{|c|}{48} & \multicolumn{4}{|c|}{292} & \\
\hline & $\overline{\mathrm{SQL}}$ & SQG & SYL & SYG & $\overline{\mathrm{SQL}}$ & SQG & SYL & SYG & \\
\hline$\overline{\mathrm{pH}}$ & 4.8 & 4.9 & 4.9 & 4.6 & 4.9 & 4.8 & 4.8 & 4.7 & 4.8 \\
\hline Organic matter $\left(\mathrm{g} \cdot \mathrm{kg}^{-1}\right)$ & 5.3 & 5.1 & 5.5 & 5.3 & 5.1 & 5.6 & 5.8 & 5.0 & 5.3 \\
\hline $\mathrm{C}(\%)$ & 20 & 18 & 20 & 19 & 21 & 21 & 19 & 18 & 19 \\
\hline N (\%) & 2 & 2 & 2 & 3 & 2 & 2 & 2 & 2 & 2 \\
\hline $\mathrm{C}: \mathrm{N}$ & 9.8 & 9.2 & 10.0 & 9.5 & 10.3 & 10.3 & 9.7 & 9.0 & 9.7 \\
\hline $\mathrm{NH}_{4}\left(\mathrm{mg} \mathrm{NH}{ }_{4}-\mathrm{N} / \mathrm{kg}\right)$ & 2.1 & 2.6 & 2.3 & 1.9 & 2.7 & 2.7 & 2.5 & 1.9 & 2.4 \\
\hline $\mathrm{NO}_{3}(\mathrm{mg} \mathrm{NO}-\mathrm{N} / \mathrm{kg})$ & 0.5 & 0.5 & 0.5 & 0.4 & 0.5 & 0.5 & 0.6 & 0.4 & 0.5 \\
\hline $\mathrm{PO}_{4}\left(\mathrm{mg} \mathrm{PO} \mathrm{PO}_{4}-\mathrm{P} / \mathrm{kg}\right)$ & 9.6 & 9.5 & 9.2 & 10.0 & 9.4 & 9.2 & 9.5 & 8.3 & 9.1 \\
\hline Moisture (\%) & 20.7 & 20.7 & 20.9 & 20.9 & 20.5 & 20.2 & 20.6 & 20.6 & 20.8 \\
\hline
\end{tabular}

${ }^{\mathrm{z}}$ Values are means across all replications and sampling dates. No significant differences were observed among treatments or over time.

which is adequate for healthy, established turfgrass growth based on Olsen test recommendations for sodium-bicarbonate extractions (low $=$ less than 8 ; adequate $=8$ to 18 ; high $=$ greater than $\left.18 \mathrm{mg} \cdot \mathrm{kg}^{-1}\right)($ Rosen et al., 2008). Neither organic nor synthetic fertilizer treatments had mean soil $\mathrm{PO}_{4}$ values significantly different from the NF control treatment (Table 1), indicating that fertilizer type, formulation, and rate did not influence soil $\mathrm{PO}_{4}$ levels and that SQL and SQG are unlikely to present a phosphorus $(\mathrm{P})$ pollution risk. Furthermore, bimonthly measurements of $\mathrm{PO}_{4}$ in soil pore water (Fetter et al., 2011) showed that squid hydrolysate fertilizer does not pose a $P$ pollution threat to groundwater. Our results are in agreement with previous studies indicating that organic and synthetic fertilizers have little influence on soil $\mathrm{PO}_{4}$ concentrations (Cheng et al., 2008; Gaudreau et al., 2002; Petrovic et al., 2005).

The soil at the study site typically contains $5 \%$ organic matter. No significant differences were observed among fertilizer treatments for soil $\mathrm{C}$ and $\mathrm{N}$ content, $\mathrm{C}: \mathrm{N}$ ratio, and $\mathrm{SOM}$ (Table 1). This was expected as a result of the relatively high initial SOM levels and short duration of our project. Previous studies have shown organic fertilizer amendments can take up to 15 years of application to increase SOM on fine-textured soils (Cheng et al., 2008).

Heavy metal contamination is frequently a concern when urban or industrial wastes are used as organic fertilizers. Squid hydrolysate had a higher zinc ( $\mathrm{Zn})$ content than either of the synthetic fertilizers (127 and $160 \mathrm{mg}$ $\mathrm{Zn} / \mathrm{kg}$ for SQL and SQG, respectively, vs. 48 and $50 \mathrm{mg} \mathrm{Zn} / \mathrm{kg}$ for SYL and SYG). Both squid-based products contained detectable levels of arsenic (23 and $17 \mathrm{mg} \cdot \mathrm{kg}^{-1}$ in SQL and SQG, respectively), which was not detected in the synthetic products. Additionally, SQG contained $132 \mathrm{mg} \cdot \mathrm{kg}^{-1}$ chromium and 13 $\mathrm{mg} \mathrm{lead} / \mathrm{kg}$. Nickel was not detected in any fertilizer. Although these levels are low, trace metals in fertilizer may accumulate in soil after repeated applications. Trace metals in soils are monitored to limit the amount of pollution from runoff or leaching events (Sistani and Novak, 2006). Fertilizer treatments had no significant effect on trace metal levels in soil (data not shown). There was a trend of increasing $\mathrm{Zn}$ levels over time in the fertilized plots that was not present in the NF control plots. This trend was not apparent for the other metals, and $\mathrm{Zn}$ levels were not consistently higher in the plots receiving squid-based fertilizer.

Microbial activity. Microbial activity is closely related to soil fertility through mineralization of organic forms of nutrients from SOM and dead microbial biomass into plant-available inorganic forms of nutrients (Frankenberger and Dick, 1983). Inorganic $\mathrm{N}$ release from organic materials, either present in or added to soil, is dependent on microbial mineralization (Hadas et al., 1996; Qian et al., 2003). We measured dehydrogenase activity, an intracellular enzyme involved in microbial oxidoreductase metabolism 
(García-Gil et al., 2004), to assess the effects of fertilizer treatments on soil microbial activity.

When microbial activity was analyzed over the entire two-year period as a three-way factorial, only the main effects of fertilizer type and formulation were significant. Both liquid formulations produced significantly higher microbial activity than the granular products applied at the same rate (Fig. 3A), and the squid hydrolysate products produced higher microbial activity than the synthetic products. Liquid fertilizer may have increased microbial activity compared with granular products as a result of the decreased time and lower energy required by microbes to break them down. This would result in a greater amount of nutrients released more quickly to plants and microorganisms. The positive effect of organic fertilizers on microbial activity levels may be the result of the high $\mathrm{C}: \mathrm{N}$ ratio of squid hydrolysate relative to synthetic fertilizers, which supply a high amount of $\mathrm{N}$ and no $\mathrm{C}$. Adequate $\mathrm{C}: \mathrm{N}$ ratios are necessary to support a large microbial population, which requires both $\mathrm{C}$ and $\mathrm{N}$ for growth.

There were significant differences in microbial activity among products. Squid liquid fertilizer had the highest microbial activity followed by SQG (Fig. 3B). Both squidbased products had significantly higher activity than SYG, and SQL was significantly higher than SYL. There were no significant differences between the two squid-based products, whereas SYL was associated with significantly higher microbial activity than SYG.

The microbial activity values in our study ranged from less than 0.1 to greater than
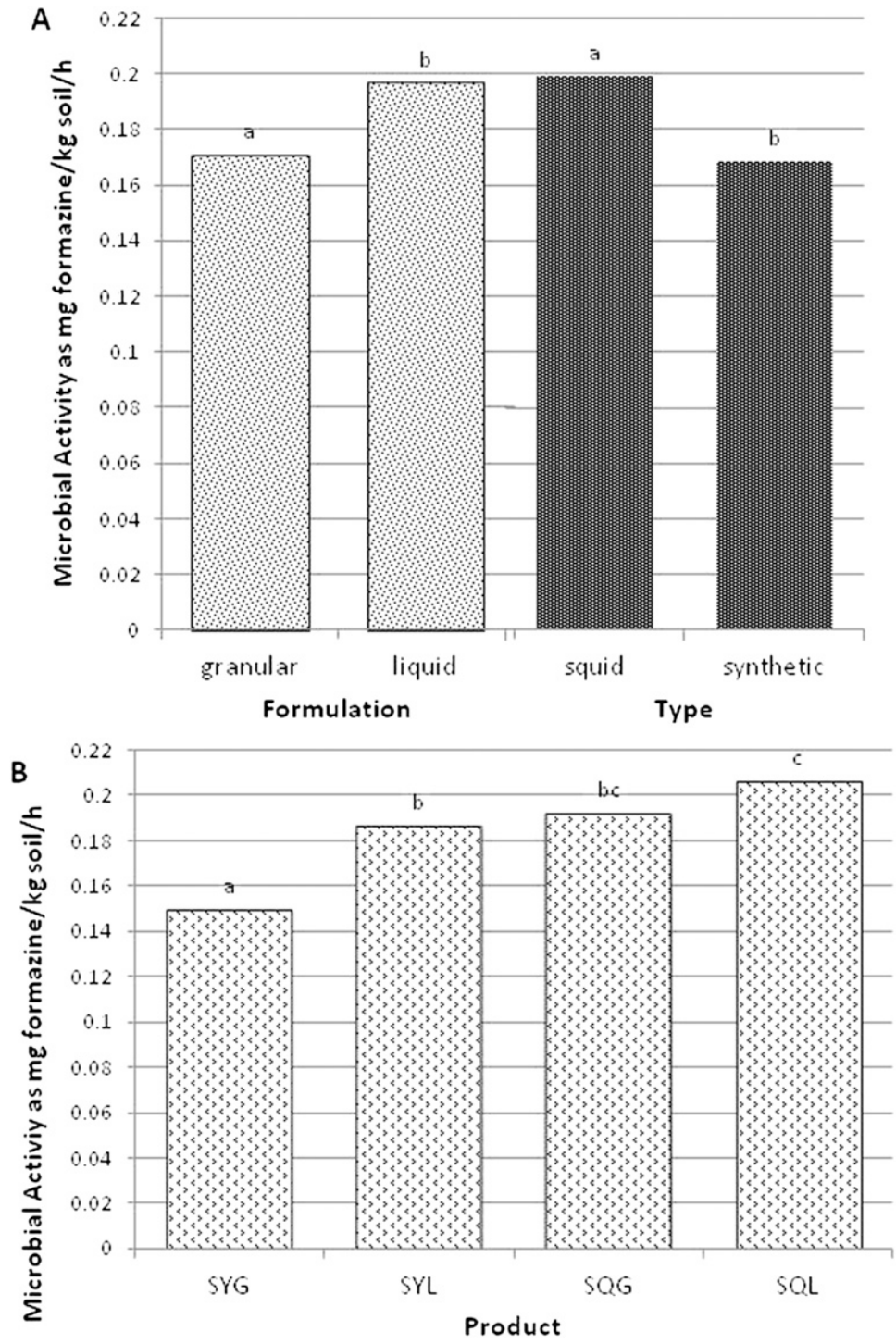

Fig. 3. Least square means from repeated measures analysis of soil microbial activity in perennial ryegrass plots fertilized with four different fertilizers. Microbial activity was measured as dehydrogenase activity. Means represent four replications and eleven sampling dates over two years. (A) Least square means for fertilizers grouped by formulation and type. (B) Least square means for the four fertilizer products across all rates. Bars with the same letter are not significantly different at $P<0.05$. SQG $=$ squid-based granular; $\mathrm{SQL}=$ squid-based liquid; $\mathrm{SYG}=$ synthetic granular; $\mathrm{SYL}=$ synthetic liquid.

$0.3 \mathrm{mg}$ formazan $/ \mathrm{kg} / \mathrm{hour}$ for all treatments. These values are within the range of those reported by García-Gil et al. (2004) on a semiarid sandy-textured soil, low in SOM with a low C:N ratio. Similar to our results, they found that additions of organic fertilizers increased microbial activity over a no-fertilizer control. By contrast, other studies have found availability of $\mathrm{C}$ and $\mathrm{N}$ to microorganisms to be more important factors influencing microbial activity than fertilizer source (Cheng et al., 2008; Hadas et al., 1996; Shi et al., 2006b). Groffman et al. (1996) observed that microbial activity levels were dependent on soil texture rather than fertilizer application. Soils that were finer in texture had higher $\mathrm{C}$ and $\mathrm{N}$ levels, along with higher soil moisture levels, relative to coarse-textured soils. Other studies have shown microbial activity to increase with turfgrass stand age (Shi et al., 2006a, 2006b). Young turfgrass strands, like those in our study, have lower microbial activity compared with well-established turf.

\section{Conclusions}

Our data suggest that squid hydrolysate can be effective as an organic fertilizer applied to turfgrass. Squid hydrolysate applied as a liquid and granular fertilizer consistently provided high-quality, uniform turf when compared with synthetic fertilizers applied at the same rate. Levels of soil $\mathrm{NO}_{3}, \mathrm{NH}_{4}$, $\mathrm{PO}_{4}, \mathrm{pH}$, moisture, organic matter, $\mathrm{C}: \mathrm{N}$ ratios, and concentrations of heavy metals were unaffected by fertilizer type, formulation, or rate throughout the two-year study. Microbial activity levels were highest in plots fertilized with liquid and organic fertilizer. Plots treated at the highest application rate also had higher microbial activity. Our results suggest that SQL applied at the highest rate has the greatest potential to increase microbial activity. Our data appear to support claims that organic fertilizers have the potential to increase microbial activity levels in soil.

Although soil $\mathrm{NO}_{3}, \mathrm{NH}_{4}$, and total $\mathrm{N}$ analyses indicated no significant differences relative to fertilizer type, formulation, or rate, increased $\mathrm{N}$ application rate resulted in increased turfgrass uniformity. As a result of rapid oxidation, leaching, plant uptake, and volatilization of $\mathrm{N}$, soil analyses may not be appropriate indicators of soil $\mathrm{N}$ availability. Other analyses such as turf quality and clipping production should be considered as better indicators of $\mathrm{N}$ availability to turf.

As $\mathrm{N}$ application rate increased, the most important attributes associated with healthy turfgrass - turf quality and clipping production-improved. Our results indicate that squid hydrolysate provides soil nutrient concentrations and turfgrass quality similar to synthetic fertilizer applied at the same rate. Despite the claims that organic fertilizers improve turfgrass quality through higher microbial activity and biomass levels in soil, our results showed that $\mathrm{N}$ application rate was the most influential factor improving turfgrass quality. 
Carbon additions from squid hydrolysate did not significantly generate a greater level of total C over the two-year study; however, other studies have shown that organic amendments take multiple years to generate additional $\mathrm{C}$ in the soil. Use of squid hydrolysate as fertilizer appears not to increase soil heavy metal levels, but longer-term studies are needed for conclusive evidence. Squid hydrolysate has the potential to turn waste material into a marketable product, easing the economic burden of disposal on squid processors.

\section{Literature Cited}

Booze-Daniels, J.N. and R.E. Schmidt. 1997. The use of slow release nitrogen fertilizers on the roadside: A literature review. Virginia Transportation Research Council, Charlottesville, VA. Jan. 2013. <http://www.filebox.vt.edu.aniel/ pdf/Slow\%20N\%202.pdf $>$

Brady, N.C. and R.R. Weil. 2002. The nature and properties of soils. 13th Ed. Prentice Hall, Englewood Cliffs, NJ.

Bushoven, J.T., Z. Jiang, H.J. Ford, C.D. Sawyer, R.J. Hull, and J.A. Amador. 2001. Stabilization of soil nitrate by reseeding with perennial ryegrass following sudden turf death. J. Environ. Qual. 29:1657-1661.

Cheng, Z., P.S. Grewal, B.R. Stinner, K.A. Hurto, and H.B. Hamza. 2008. Effects of long-term turfgrass management practices on soil nematode community and nutrient pools. Appl. Soil Ecol. 38:174-184.

Christians, N.E. 1996. Phosphorus nutrition of turfgrass. Golf Course Mgt. 64:54-57.

Eguiza, J.E., J.L. Eggens, and K. Carey. 1991. Composted sewage sludge as a nitrogen source for the maintenance of putting green and fairway type turf. Guelph Turfgrass Inst. Ann. Rep. 5:9-20.

Elliott, M.L. and E.A. Des Jardin. 1999. Effect of organic nitrogen fertilizers on microbial populations associated with bermudagrass putting greens. Biol. Fertil. Soils 28:431-435.

Fetter, J.C., R.N. Brown, J.H. Görres, C. Lee, and J.A. Amador. 2011. Nitrate and phosphate leaching under turfgrass fertilized with a squidbased organic fertilizer. Water Air Soil Pollut. 223:1531-1541.

Frankenberger, W.T., Jr. and W.A. Dick. 1983. Relationships between enzyme activities and microbial growth and activity indices in soil. Soil Sci. Soc. Amer. J. 47:945-951.

García-Gil, J.C., S.B. Ceppi, M.I. Velasco, A. Polo, and N. Senesi. 2004. Long-term effects of amendment with municipal solid waste compost on the elemental and acidic functional group composition and $\mathrm{pH}$-buffer capacity of soil humic acids. Geoderma 121:135-142.

Gaudreau, J.E., D.M. Vietor, R.H. White, T.L. Provin, and C.L. Munster. 2002. Response of turf and quality of water runoff to manure and fertilizer. J. Environ. Qual. 31:1316-1322.

Ginting, D., A. Kessavalou, B. Eghball, and J.W. Doran. 2003. Greenhouse gas emissions and soil indicators four years after manure and compost applications. J. Environ. Qual. 32: 23-32.

Gong, P. 1997. Dehydrogenase activity in soil: A comparison between the TTC and INT assay under their optimum conditions. Soil Biol. Biochem. 29:211-214.

Groffman, P., P. Eagan, W.M. Sullivan, and J. Lemunyon. 1996. Grass species and soil type effects on microbial biomass and activity. Plant Soil 183:61-67.

Hadas, A., L. Kautsky, and R. Portnoy. 1996. Mineralization of composted manure and microbial dynamics in soil as affected by long-term nitrogen management. Soil Biol. Biochem. 28:733-738.

Hendershot, W.H., H. Lalande, and M. Duquette. 1993. Soil reaction and exchangeable acidity, p. 173-178. In: Carter, M.R. (ed.). Soil sampling and methods of analysis. Lewis Pub., Ottawa, Ontario, Canada.

Hull, R.J. and J.T Bushoven. 2001. A metabolic approach improving nitrogen use efficiency in turfgrasses. USGA Green Section Record 39:16-17.

Hummel, N.W., Jr. 1989. Resin-coated urea evaluation for turfgrass fertilization. Agron. J. 81: 290-294.

Jiang, Z., J.T. Bushoven, H.J. Ford, C.D. Sawyer, J.A. Amador, and R.J. Hull. 2000. Mobility of soil nitrogen and microbial responses following the sudden death of established turf. J. Environ. Qual. 29:1625-1631.

Keeney, D.R. 1982. Nitrogen-Availability indices. Methods of soil analysis. Part 2. Chemical and Microbiological Properties. p. 711-733.

Landschoot, P.J. and D.V. Waddington. 1987. Response of turfgrass to various nitrogen sources. Soil Sci. Soc. Amer. J. 51:225-230.

Lian, P.Z., C.M. Lee, and E. Park. 2005. Characterization of squid-processing byproduct hydrolysate and its potential as aquaculture feed ingredient. J. Agr. Food Chem. 53:55875592.

Mancino, C.F., W.A. Torello, and D.J. Wehner. 1988. Denitrification losses from kentucky bluegrass sod. Agron. J. 80:148-153.

McCarty, L.B., I.R. Rodriguez, B.T. Bunnell, and F.C. Waltz. 2003. Fundamentals of turfgrass and agricultural chemistry. Wiley, Hoboken, NJ.

Milwaukee Metropolitan Sewage District. 2013. Specifications. 12 Jan. 2013. <http://www.milorganite. com/en/Using-Milorganite/Specifications.aspx $>$.

Nardi, S., F. Morari, A. Berti, M. Tosoni, and L. Giardini. 2004. Soil organic matter properties after 40 years of different use of organic and mineral fertilisers. Eur. J. Agron. 21:357-367.

Petrovic, A.M., D.D. Soldat, J. Gruttadaurio, and J. Barlow. 2005. Turfgrass growth and quality related to soil and tissue nutrient content. Intl. Turfgrass Soc. Res. J. 10:989-997.

Qian, Y.L., W. Bandaranayake, W.J. Parton, B. Mecham, M.A. Harivandi, and A.R. Mosier. 2003. Long-term effects of clipping and nitrogen management in turfgrass on soil organic carbon and nitrogen dynamics: The CENTURY model simulation. J. Environ. Qual. 32:16941700.

Rector, D.D. 1981. Soil survey of Rhode Island. US Department of Agriculture, Soil Conservation Service.

Rosen, C.J., P.M. Bierman, and R.D. Eliason. 2008. Soil test interpretations and fertilizer management for lawns, turf, gardens, and landscape plants. University of Minnesota, St. Paul, MN.

Rossi, F.S. 2006. Effects of microbial and organic products on putting green performance. Golf Course Mgt. 74:101-105.

Rynk, R., M. van de Kamp, G.B. Wilson, M.E. Singley, T.L. Richard, J.J. Kolega, F.R. Gouin, L. Lalibery, Jr., D. Kay, D.W. Murphy, H.A.J. Hoitink, and W.F. Brinton. 1992. Onfarm composting handbook. NRAES, Ithaca, NY.

Schoenau, J.J. and R.E. Karamanos. 1993. Sodium bicarbonate-extractable $\mathrm{P}, \mathrm{K}$, and N, p. 51-58. In: Carter, M.R. (ed.). Soil sampling and methods of analysis. Lewis Pub., Ottawa, Ontario, Canada.

Shi, W., S. Muruganandam, and D.C. Bowman 2006a. Soil microbial biomass and nitrogen dynamics in a turfgrass chronosequence: A short-term response to turfgrass clipping addition. Soil Biol. Biochem. 38:2032-2042.

Shi, W., E. Dell, D. Bowman, and K. Iyemperumal 2006b. Soil enzyme activities and organic matter composition in a turfgrass chronosequence. Plant Soil 288:285-296.

Sistani, K.R. and J.M. Novak. 2006. Trace metal accumulation, movement, and remediation in soils receiving animal manure, p. 689-706. In: Prasad, M.N.V., et al. (eds.). Trace elements in the environment: Biogeochemistry, biotechnology, and bioremediation. Taylor \& Francis, New York, NY

Sullivan, D.M., J.M. Hart, and N.W. Christensen. 1999. Nitrogen uptake and utilization by $\mathrm{Pa}$ cific Northwest crops. Pacific Northwest Extension Bulletin 513

Torello, W.A., D.J. Wehner, and A.J. Turgeon. 1983. Ammonia volatilization from fertilized turfgrass stands. Agron. J. 75:454-456.

Turgeon, A.J. 2012. Turfgrass management. 9th Ed. Prentice-Hall, Englewood Cliffs, NJ.

Wright, A.L., T.L. Provin, F.M. Hons, D.A. Zuberer, and R.H. White. 2008. Compost impacts on dissolved organic carbon and available nitrogen and phosphorus in turfgrass soil. Waste Mgt. 28:1057-1063.

Zuberer, D.A. 2005. Microbes in soil and sand-based root zones: A few of the basics. SportsTurf 21:8, $10-12$. 